\title{
THE ANTI-CORRUPTION CIVIL SOCIETY IN SWEDEN AS PART OF SUSTAINABLE POLICY NETWORKS
}

\author{
MARINA MAKAROVA ${ }^{1}$ \\ Udmurt State University (Russia)
}

\begin{abstract}
The article aims to define how the main principles of the Swedish welfare state, i.e., the "multi-stakeholder principle" and the principle of trustfulness and collaboration, affect activity of the anti-corruption civil society. For the study, the following empirical methods have been used: the analysis of documents and in-depth-interviews with experts. The author demonstrates that the anti-corruption activity of civil society in Sweden can be considered as part of wider social movements for human rights, democracy and integrity, especially at international level. There are a lot of associations and unions in Sweden that, among other joint activities, promote anti-corruption practices and rules in state organisations and commercial enterprises. The state and government need to be oriented to social challenges and keep pace with civic movements. A partnership with different stakeholders is the main type of the Swedish ACS's activities that help to reach their goals in preventing corruption behaviour, e.g., "Anti-corruption policy networks", and it is the result of two types of collaboration: anti-corruption participation and anti-corruption services. The research has shown that the civil society's ability to create networks with the state, business and other agents is the main condition for the so-called horizontal accountability and sustainability and for preventing corruption in Swedish society that, in its turn, has been established over a long period of time building the culture of integrity and civic institutions.
\end{abstract}

KEYWORDS: corruption, civil society, policy networks.

JEL CODES: H7, I0, I3.

DOI:

\section{Introduction}

The Anti-Corruption Civil Society (ACS) has become a comprehensive system that includes many agents, different coalitions and forms of activity around the world. It is one of the main providers of anticorruption policy. The anti-corruption civil society includes two main aspects. Broadly construed, it means "individuals and groups outside the public sector" that promote values of integrity and accountability in society (Holloway, 2006). This aspect includes not only different sorts of Non-Governmental Organisations (NGOs), community and business associations, but also presupposes the participation of citizens outside of formal organisations. In this aspect, the anti-corruption civil society may include active individuals, journalists, local activists, etc. The other aspect, in its "narrow" sense, refers to the so-called "institutionalised civil society" that includes anti-corruption NGOs and other formal organisations and associations that deal with anti-corruption issues (The World Bank's Strategy, 2017).

The ACS study is a relatively new area in social sciences. For this reason, the concept of ACS needs to be systematised through analysis of its functioning in countries with different levels of political and social development. According to the main research in this domain, the most critical and conflict zones and borderlines in ACS' development are the relations between international and domestic civil society organisations, and the ACS's relations with the state and business as important stakeholders of anti-corruption policy to develop

Marina Makarova - Udmurt State University, Universitetskaya Str. 1, 426034, Izhevsk, Russia.

Scientific interests: corruption, civil society.

E-mail:makmarmaru@gmail.com 
the system of check and balances and accountability for effective anti-corruption implementation (Moroff, Schmidt-Pfister, 2010; Heinrich, Brown, 2017).

The main ACS's functions in fighting against corruption include the following areas: research and other related activities; advocacy works in some corruption cases; raising public awareness about corruption issues; proposing action plans in fighting corruption; monitoring government actions and decisions; providing leadership to remove corrupt leaders at national and local levels, etc. (Holloway, 2002; UN Office of Drugs and Crime, 2004; Carr, Outhwaite, 2011).

Researchers agree that accessing the impact of civil society activity against corruption is very difficult, and the level of its development does not confirm its specific role in fighting corruption. Some researchers use the additional related factors that contribute to this impact, such as press freedom (Themudo, 2013), social trust (Rothstein, Uslaner, 2005), or the level of political culture and participation (Mungiu-Pippidi, 2013; Olsson, 2014). At the same time, all of those factors refer to the level of democracy and political and economic liberties in society that are plainly determined from the state governance, government's "political will" to collaborate with civil society and support freedom of expression in society. Civil society is intended to contribute to a system of "checks and balances" that holds government and other funders accountable, as well as controls business transparency, especially in its relation with authority (Themudo, 2013; Elliott, 1997).

Swedish ACS is one of the specific examples of non-governmental agents' relations with different stakeholders in preventing corruption. Civil society in Sweden plays an important role in preventing anticorruption practice in the country and around the world. At the same time, Swedish ACS is a part of the broad system of civil society as the necessary component of the new model of social welfare state where the government becomes only one of many different players (Pestoff, 2008).

Contemporary welfare state policies include multiple policies at different levels. Sweden has long-time traditions of civil participation "rooted in the new mass organisations emerging in the late 19th century, beginning to become institutionalised as the dominating civil society paradigm in Sweden in the decades around the Second World War." (Wijkström, 2004: 20) An estimated 200,000 organisations are parts of the Swedish civil society. More than 85 percent of the population aged 16-84 are members of an association. The level of self-sufficiency in Swedish civil society is higher than the average for the EU countries (A policy for civil society, 2010).

Sweden is one of the countries with the lowest level of corruption around the world. The main feature of Swedish society directly related with the low level of corruption in Sweden is based on the high level of public trust in society. Low corruption can be both a factor and a consequence of high public trust. Low level of corruption leads to "more universalistic social welfare programs and to greater generalised trust." (Rothstein, Eek, 2009: 85) At the same time, high level of public participation and support to the state policy creates opportunities for greater public accountability and institutional integrity (Svallfors, 2011). According to the European Values Survey, Sweden and Denmark are the most trusting countries in the EU. The three Scandinavian countries - Denmark, Sweden and Finland - top the list with scores from 66.5\% to 58\% (Graeff, Svendsen, 2013). Other estimations show the continuity in people's support for the main welfare policies in Sweden; "more people express their willingness to pay higher taxes for welfare policy purposes" (Svallfors, 2011). High level of social trust and trust in government officials in Sweden (vertical and horizontal) are connected with collaboration and partnership as the main ideological principle of Swedish society. The most significant and relatively stable form of partnership in Sweden is a close collaboration between the state and mass movements: "Relationship between voluntary organisations and the state in Sweden, and in Scandinavia more generally, has been one of close cooperation, more so than of competition or conflict" (Rothstein, 2001: 214).

The ACS research is a relatively new area in social sciences. For this reason, the main research problem is that the concept of ACS needs to be systematized. Sweden is one of the good examples of collaboration between public, private, and civil society agents for fighting against corruption. This experience can be useful for different, especially post-Soviet countries that try to create an effective anti-corruption policy. At the same time, the challenges for anti-corruption institutions in Sweden should be analysed. Thus, the following issues need to be clarified in this article: 
1. The structure of Swedish ACS (elements, or levels, e.g., NGOs, local communities, business associations, etc.) has not been properly investigated. Some of the entities that provide anticorruption work independently from the state, need to be concretized as a specific level or aspect of ACS (e.g., business associations). Others, in their turn, have a strong connection with the state, and also need to be analysed as a specific element of civil society.

2. The functioning of international and domestic ACS is insufficiently presented in the research literature, especially in terms of their interaction. Sometimes their goals in anti-corruption activity are ambiguous and contradict each other.

3. The effectiveness of ACS in the implementation of international and national anti-corruption policies in the specific national conditions is unclear, and difficult to measure. In this regard, it is necessary to determine the role of different agents: NGOs, state, media etc. in fighting corruption in Sweden.

This article is aimed to define how the main principles of Swedish welfare state - the "multi-stakeholder principle" and the principle of trustfulness and collaboration - affect the activity of anticorruption civil society. The three main objectives are connected with this aim: first, there will be considered the ACS's structure and forms of activity regarding the most problematic spheres and types of corruption in Sweden; second, there will be identified the forms of ACS' relationship with the state, business, and other civic institutions; third, the author will try to elaborate the main ways of the ACS' self-presentation by defining some roles of ACS in fighting against corruption in Swedish society.

Therefore, the following empirical methods will be used for the study:

1. The analysis of documents, such as the country's laws and regulations, projects of anti-corruption organisations and reports on their activity, analytical materials of international and domestic organisations, publications in the mass media, websites, information booklets, and other materials.

2. In-depth-interviews with experts related to ACS (18 interviews in total): heads and members of international and national anti-corruption NGOs, and those of organisations and foundations doing some anticorruption activity to rise their effectiveness (charity, trade unions, etc.); representatives of the mass media, open data sources, and journalists; members of business associations, compliance officers; representatives of public anti-corruption authorities or agencies.

\section{Corruption in Sweden and ACS's anticorruption activity}

Sweden is usually ranked by different institutes (e.g., Transparency International, GRECO, and Eurobarometer) among the least corrupt countries in the world. In 2017, Sweden had Corruption Perception Index score 84 , and is always ranked among the first five-six less corrupt countries in the world (Corruption Perceptions Index, 2018). The last Eurobarometer survey shows very low acceptance of any corruption by Swedish citizens. At the same time, corruption still remains in Swedish society: 37\% of Swedish people believe that corruption is widespread in their country (Special Eurobarometer, 2017: 17). It is still the third least amount in the EU, however it says about some dissatisfaction with the level of integrity in the society. Since the early 2000s, Sweden has been criticised regarding its weaknesses in the sphere of measuring and fighting corruption in public authorities. For instance, GRECO noticed the lack of regulation of political parties' financing; insufficient forms of investigation and prosecution of corruption-related cases; necessity to work in the public sector to provide internal awareness and staff training for improving their knowledge and skills in curbing corruption (Bergh, Sjolin, 2016: 44-45). The National Anti-Corruption Unit as a national prosecution office has been acting in its present form since 2005. In 2012, the Swedish National Anti-Corruption Police Unit (NACPU) has been established as a national resource that fights against corruption-related crimes in cooperation with the National Anti-Corruption Unit of the Swedish Prosecution Authority.

The Swedish anti-corruption activities and initiatives are first of all based on certain methodological approaches to corruption that have been defined not only by legislation but also by some theoretical investigations. The Swedish legislation is mainly anti-bribery. The anti-bribery provisions in the Swedish law are set out in the Swedish Penal Code and apply equally to domestic and foreign bribery (Swedish 
Anti-Corruption Legislation, 2016). As part of the recent review of the anti-corruption legislation, the laws were supplemented by a "Code on Gifts, Rewards and Other Benefits in Trade and Industry" (the "Business Code"). This Code was prepared in collaboration with the business sector and was then adopted by the Swedish Anti-Corruption Institute. The Business Code does not have the status of a law, however, it serves "as a complement intended to clarify the legislation on bribery, which is written in very general terms and often difficult to interpret" (The Anti-Bribery and Anti-Corruption Review, 2014: 260).

As for the theoretical perspective of understanding Swedish corruption, one may see that researchers are prone to define corruption "in a broad sense" (Bergh, Sjolin, 2016; Andersson, 2002) that involves not only traditional forms of corruption but also other ethical issues that sometimes have ambiguous nature and are hardly evincible in a legal process. The Swedish National Council for Crime Prevention (Brå) defined corruption very broadly as the abuse of power (Reported Corruption in Sweden, 2013: 16).

The ways of 'extension' of the term 'corruption' used both in public and private sectors include the following two main directions: nepotism- and favouritism-related cases, and situations with gifts and favours. Researchers explain the wide discussions in the country about political and business ethics by low incidence of corruption in Sweden, and by low acceptance in society of most of the forms of misbehaviour, including favouritism and gifting. Thus, 85 percent of Swedish citizens believe that giving a gift to a public official is unacceptable (the average in the EU countries is 76 percent) (Special Eurobarometer 470, 2017).

The main risk spheres of corruption in Sweden have split almost equally between the state sector, the local government sector, and the private sector (see Table 1).

Table 1. The main spheres of corruption in Sweden

\begin{tabular}{|l|l|l|}
\hline \multicolumn{1}{|c|}{ Sector } & \multicolumn{1}{|c|}{ Spheres } & \multicolumn{1}{c|}{ The most famous cases } \\
\hline Central government sector, 27\% & $\begin{array}{l}\text { Swedish Armed Forces, the Prison and } \\
\text { Probation Service, the agencies for } \\
\text { road administration and air navigation } \\
\text { services; } \\
\text { employees of state-owned companies }\end{array}$ & $\begin{array}{l}\text { A former property manager } \\
\text { at the Swedish Prison and Probation } \\
\text { Service accepted bribes (2014) } \\
\text { were changers of Systembolaget stores } \\
\text { from suppliers in 2005 }\end{array}$ \\
\hline Local government sector, 26\% & $\begin{array}{l}\text { Technical administration, social } \\
\text { services, and in planning and } \\
\text { municipal leadership, and } \\
\text { Mayors }\end{array}$ & $\begin{array}{l}\text { Gothenburg case (2010): } \\
\text { misuse of office committed by local } \\
\text { government officials in collaboration } \\
\text { with privately } \\
\text { owned construction companies } \\
\text { offering excessive benefits to the } \\
\text { municipal officials }\end{array}$ \\
\hline Private sector, 34\% & $\begin{array}{l}\text { Construction and civil engineering, } \\
\text { manufacturing and the wholesale and } \\
\text { retail trade }\end{array}$ & $\begin{array}{l}\text { 'Telia' (2007-2010) has admitted to } \\
\text { making illegal payments of SEK 2.6 } \\
\text { billion to various Uzbek government } \\
\text { officials to win business contracts in } \\
\text { the country }\end{array}$ \\
\hline
\end{tabular}

Source: Reported Corruption in Sweden (2013); The Anti-Bribery and Anti-Corruption Review (2014).

According to different sources, including interviews from the police and prosecution authority, the most often cases with grand and business corruption are connected with violations in public procurement, especially at the municipal level, which is relatively autonomous from the central government. Ove the last years, within the proactive work of different offices, such as NACPU, National Council for Crime Prevention, National Audit Office, etc., these cases were mostly restricted to giving improper gifts and favouritism in order to get the contract. The other vulnerable area is care to the elderly, most often involving patient appreciation of services by caretakers who received money or expensive gifts. Persons responsible for issuing permits 
and approvals also "run the risk of exposure to corruption" (Andersson, 2002). They can receive bribes from individuals and businesses for inspecting vehicles, serving alcohol, registering food establishments and granting building permits. (Reported Corruption in Sweden, 2013). The most vulnerable question nowadays is corruption at the international level. Companies sometimes cannot make business in the developing world without some misbehaviour. The ethical issue in public and private sectors is a matter of concern both in the public sector and in business. For this reason, regular measures on the implementation of codes of conduct and the rules of ethical behaviour in companies and public offices become the main agenda.

Civil society in Sweden working in the anti-corruption sphere can be divided in different levels. The first level includes the anti-corruption organisations themselves. There are two main anti-corruption NGOs in Sweden: Transparency International (TI) and the Swedish Anti-Corruption Institute (Institutet Mot Mutor, IMM). These two organisations interact closely and present a good partnership of international and national civil society. TI Sweden has been created in 2004 as a national chapter of the greatest international anticorruption organisation "Transparency International". TI Sweden works on preventing corruption, minimising risks of corruption both in the public and private sectors. TI's work with the public sector is intended mostly to the participation in discussion and lobbying for changes in anticorruption legislation. Collaboration with the business sector includes informational work, raising awareness and supporting partners. One of the best examples of the coordination at international level is the Corporate Supporters Forum (CSF) as a group of large companies, convened by TI Sweden, that are dedicated to promoting anti-corruption standards in the business sector. It is a form of collaboration for sharing experience of fighting against corruption, not only on paper but also in the real process of implementation for creating a better ethical business climate. Twice a year, TI Sweden organises workshops for these companies to discuss how to identify risks and develop better frameworks of anti-corruption.

The Swedish Anti-Corruption Institute, founded in 1923, is intended to support organisations in implementing anti-corruption standards based on the Code of Business Conduct. This Code elaborated in 2012, contains general ethical rules for organisational communications and recommendations to uphold high ethical standards in business and public administration. IMM supports separate organisations and business associations to adopt this code or elaborate their own code with respect to their specific spheres and issues. Organisations consult with experts about better implementation of the code and specific actions in different situations. The Ethic Committee is gathered for such specific purposes when companies want to solve some ethical dilemmas or have specific questions regarding the code. The Anti-Corruption Institute also organises trainings and seminars for the business sector, local authorities, and social employees to promote ethical standards and discuss specific cases.

The anti-corruption activity of these two non-profit organisations, on the one hand, is broad and universal; on the other hand, it is intended for the most vulnerable zones where the risk of corruption is high: public procurement, business ethics, international business, local authorities, etc.

Another type of civil society aims at the informational work, raising public awareness and providing proper tools and ways for informing about corruption and its curbing. One of the main conditions for successful fighting with corruption is transparent and open data and available sources of information.

Sweden has the oldest freedom of information act in the world that was passed in 1766. According to the Public Access to Information and Secrecy Act (2009), which entered into force on 30 June 2009, every Swedish citizen must be entitled to have free access to official documents in order to encourage the availability of comprehensive information. This long-term free environment creates the best conditions for transparency in society and prevents secrecy and impartiality in making decisions and spending public money. At the same time, the access to the information itself does not guarantee wide public interest in it. For raising people's awareness and activity in public information, special organisations and open data portals have been created. The most famous of them is the Open Knowledge Foundation that has its chapter in Sweden. Some of its projects are intended for providing information from authorities to ordinary people. One of them is the FrågaStaten project where people can ask the authorities any question by using the aggregation platform. The system sends the question to different public authorities and offices, and they have to answer it by e-mail. 
At the same time, the question and the answer are available on the website. Another example is the "Stop Secret Contract" campaign (stopsecretcontracts.org) that helps journalists and activists to fight with secrecy in public procurement and with other issues related to public financing.

A very important part of ACS connected with transparency and freedom of information is investigative journalism. The investigative journalists in Sweden feel free in disseminating information about corruption and sometimes initiate criminal investigations by the police. For example, Swedish newspapers 'Dagens Nyheter', 'Aftonbladet', TV programs 'Kalla Fakta' and 'Uppdrag granskning' publish material about corruption scandals. In 2003, one of the world-famous investigative team led by Fredrik Laurin was awarded the Swedish Investigative Journalists Prize of Honour 2003 for a story uncovering a huge bribery scandal in "Systembolaget" (the Swedish State Monopoly on Alcohol). They also investigated the largest international corruption cases with 'Telia' and 'Bombardier'.

The third large group of civil society is a business compliance system that includes different forms of business support and protection from corruption. It exists in the forms of business associations and partnerships between companies in the frameworks of different associations. At the same time, the biggest companies create their own compliance offices to develop and implement codes of conduct and anti-corruption rules and practices. All of modern compliance systems are based on the international standards and principles of sustainable development: OECD Guidelines for Multinational Enterprises (2015); UN Global Compact (2018); ILO Core Conventions (2018); UN Guiding Principles on Business and Human Rights (2011); 2030 Agenda for Sustainable Development (2015), etc. Swedish authorities try to provide compliance systems at the international level by holding international and national meetings within the framework of Swedish International Embassy, International Chamber of Commerce. Most of the compliance systems in the biggest companies include regular risk assessments, development of rules and guidelines, reporting and whistleblowing, control and sanctions, and trainings for employees at different levels. For example, after a big corruption scandal connected with bribery, 'Telia' Company had to rethink and remediate their policy fundamentally, especially in international markets. Now the company uses the tools of the Risk-Based Approach (Introducing a Risk-Based Approach 2014), and their own system of responsible business that consists of seven main components: risk assessment; resources and capabilities (e.g., establishing positions of special compliance officers); policies and instructions; education and communication (awareness-building efforts among employees, trainings); third parties (management of relationships with suppliers and partners); reporting, investigations and audit. The system should be audited continuously at different levels (external and internal). This method allows to proceed depending on the risks and conditions in a particular sector (for example, provide specific resources and policies in countries where the risk of corruption is higher), and to organise this work continuously.

The last group of ACS exists within the framework of associations that support different economic sectors or spheres where corruption occurs. There are a lot of associations and unions in Sweden that, among other joint activities, promote anti-corruption practices and rules in state organisations and businesses. For example, the Swedish Association of Local Authorities and Regions, the Swedish National Agency for Education, the Swedish Construction Clients, the Swedish Property Federation, and plenty of other different associations that unite services and businesses, take care of anti-corruption issues with varying degrees of violence, and adopt codes of conduct for specific conditions. The associations help companies, which do not have special compliance officers, to solve individual problems, to adopt ethical codes by collaboration with authorities and civil society, e.g., TI Sweden or IMM, by organising trainings, seminars, or consulting and assisting. Umbrella organisations and associations also support state and non-profit organisations in the sphere of education, sport, healthcare, and social services to develop a single approach to anti-corruption and ethical rules in particular spheres. The Swedish Sport Confederation is the umbrella organisation for sport in Sweden; its members are 71 special federations and clubs. The Federation organises proactive work in preventing match fixing by delivering trainings, reporting systems and creating ethical codes and rules. On their website, they have detailed guidelines concerning this topic that helps them to educate people and make them aware about certain dishonest actions in sport and the ways to prevent it. 
Thus, these four groups of ACS can be common for different countries; however, in the next two chapters, the author will try to find some features that characterise the Swedish ACS in the context of corruption in the country, specific to civil society, and some specific challenges and principles of anti-corruption activity in Swedish society.

\section{Anti-corruption policy networks and services: blurred lines of civil society}

Long-established traditions of social participation in Sweden produced different forms of people's membership in different associations and unions, the culture of participation and self-management. People used to solve problems of employment, social welfare and education together, with mutual understanding of their common goals (Pestoff, 2009: 121). High level of solidarity can be also explained by a high level of mutual trust in society (Rothstein, Uslaner, 2005). Different forms of civil society (trade unions, parent cooperatives, customer associations) allowed for the dialogue between producers and consumers, the state and ordinary people, and turned members into co-producing services and policies. Despite different approaches and ideas about Swedish civil society, most of researchers describe the relationship between the state and civil society in Sweden in terms of "trust-based mutual dependency" (Wijkström, 2004: 10) and "collective actions" (Pestoff, 2009: 121). The "trust-based mutual dependency" is defined as the factor of relationship of consensus and development of a corporatist model as the way people unite around for a common social issue or problem.

The Swedish civil society institutions closely collaborate with the state, business, and other non-profit organisations and associations. Researchers consider the contemporary Swedish civil society as a hybrid form of social organisations that are independent from the state, politics and any profit, and at the same time recognise that the issues they try to solve are connected with the state policy and some private services (Lundberg, 2017). For this reason, they create networks together with the state and businesses that allow exchanging resources and sharing practices, discussing the law and policies as well as changing them. Such a network model of partnership is suitable for the analysis of Swedish ACS.

A partnership with different stakeholders is the main type of the Swedish ACS's activities, which helps reach their goals in preventing corruption behaviour. The author calls these partnerships the "Anti-corruption policy networks" as they resulted from two types of collaboration: anti-corruption participation and anti-corruption services. Anti-corruption participation refers to different forms of civil society activity in cooperation with the state for elaborating rules and raising awareness about corruption in different spheres. The TI Sweden works closely with ministries by giving them recommendations for changing the legislation.

"We invited ministers to our workshops, the ministers of employment... it was our whistleblowing seminar in spring, and we also try to work directly with governmental offices, and the ministers themselves because they are important key players" (TI).

Umbrella organisations and associations also participate in the discussion with authorities about changing or adopting new laws in specific spheres - in control and preventing corruption. The Swedish Sport Confederation collaborates with the police and betting companies to discuss laws on match fixing and to educate people related to sports, especially young athletes and their parents. They have created national platform that involves all stakeholders, e.g., Swedish Sport Confederation, the state-owned gambling company 'Svenska Spel', the police, attorneys, and sports and gambling authorities.

Public anti-corruption authorities, in their turn, organise proactive outreach work with different umbrella organisations in both the public and private sectors. The Swedish National Anti-Corruption Police Unit (NACPU) performs the outreach work on a regular basis to tell people about the risks and ways to avoid them. The most popular topics for such informational visits are public procurement, conflict of interests, and also some ethical-related issues, such as favouritism and gifts. Sometimes such meetings are held with the participation of anti-corruption organisations: TI Sweden and the Swedish Anti-Corruption Institute (IMM). 
"I have invited TI and IMM, so they know that I am working in this sphere, they invite different organisations to speak about corruption... I normally go there. The Swedish Anti-Corruption Institute - we were there one week ago and discussed to the possibility of changing the law in Sweden. We go there annually and discuss what we can do. And sometimes we do presentations together, for different organisations" (NACPU).

NGOs also provide anti-corruption support services for business by assisting them in the implementation of ethical codes, and by doing educational work with different target groups. The companies understand the benefit from building networks and units for effective anti-corruption work and for ensuring a common anti-corruption language between partners at both international and national levels. Swedish companies are engaged in different international networks for making sustainable business and implementing compliance systems. The Swedish strategy of corporate social responsibility supports "voluntary participation of stakeholders." (Văduva et al., 2016: 81)

Whistleblowers' protection is very important anti-corruption service provided by private companies. 'WhistleB' provides technical and informational assistance for companies as well as governmental organisations and local authorities regarding personal data regulations and corporate ethical codes. The system protects personal data of reporters that want to be anonymous. Using special technical tools external support ensures neutrality of the receiver of the report and the whistleblowers' privacy. The specialists also assist companies in the investigations of specific cases.

"If you have whistleblower protection system you really show that you want to act, you want to do something. You can have that nicely written code of conduct and ethical guidelines and so on, but no one cares... If you have service you show that you are serious, you want to follow up" ('WhistleB').

Thus, we can see that the anti-corruption policy in Sweden, along with other policies, is a matter of different agents working together and understanding that only collaboration and a "common language" can be effective. They can see that anti-corruption civil society reflects the tendencies that characterise contemporary processes in the non-governmental sector in Sweden that takes on some state and business functions, thus consequently the borderline between their function in society gets blurred. Governmental agencies that work at international and national level invite civil society organisations to the policymaking process and create the so-called policy networks (Lundberg, 2017).

Such blurred lines and comprehensive impact from collaboration is accepted by both authorities and civil society because everyone understands the importance of goals, despite some differences in approaches.

\footnotetext{
"We have contacted authorities, but it is really difficult to measure our influence - was it really us, who contributed to the fact that the law has been changed, or not. We can see a change, in what we would like to see it, regardless of whether it was with our contribution or someone else's. If we take whistleblowing as an example, the legislation is strengthening in accordance with what we have wished for. And we are happy" (TI).

"So, I think it is important that there are different organisations that can help the public and private sector, and IMM normally helps private companies and other organisations, as well as municipalities, and we have municipal umbrella organisations that help municipalities in healthcare, etc., and we also have materials that they can use in their internal work against corruption, and for me, it is important to visit both the private sector, umbrella organisations, and the public sector" (NACPU).
}

At the same time, researchers indicate a new tendency of bringing Swedish civil society organisations "into a more market-like environment than earlier, where profit-oriented agents are also operating" (Wijkström, 2004). This characteristic applies first of all to the service-oriented organisations that are developing in the sphere of compliance and responsible business. This form of social entrepreneurship has become popular in countries that do international business and have to take care about their sustainability. At the same time, anti-corruption and compliance officers in the business sector are also becoming a part of civil society be- 
cause their activity is shifted to not-profit goals, like sustainability and responsibility. Business is becoming value-based, trustful, and responsive to social expectations.

Besides, NGOs also provide services for business for better organising their activities and raising awareness; we can see it in the project "Together Against Corruption", the Swedish Anticorruption Institute's activities, etc. However, compliance work for business has become a matter of different international networks. Such services can help maintaining independency in solving some corruption and ethical issues.

\section{Challenges and principles for future activities}

The main challenge for ACS in Sweden is implementation of the anti-corruption programs and rules. Despite of being a country with universalist culture, Sweden is not totally free from corruption and unethical behaviour. All of anti-corruption agents agree that strict rules and codes of conduct need to be properly adopted and implemented in specific circumstances, depending on the sector and organisation. The Swedish Anti-Corruption Institute elaborated a flexible code of conduct to adjust benefits for three groups: for those who exercise public authority or decide on public procurements; for other categories where particular restriction should be observed (public entities, private banks, etc.); and for employees or contractors in private companies (Code on Gifts, 2014).

The most important issue is the international business that has to implement codes of conduct and compliance rules in different partner countries. Differences in culture, especially growth of corruption in some countries, create risks and shows the need to organise control and implement the compliance system. International companies tighten their control over international branches, and at the same time, try to be sensitive for certain countries to create relevant policy against corruption. For this reason, the local expertise becomes important to understand a country and create a relevant policy of compliance. Consequently, the first principle that all anti-corruption agents, including ACS, follow in the course of their activity is risk assessment. The assessment of potential risks is one of the main forms of TI Sweden's activity. This area is in focus because the main component of anti-corruption activity is proactive work to prevent corrupt and unethical behaviour.

"We are not really pointing fingers or working with illegal cases, we are working on how to prevent corruption, how to minimise the risks of corruption in public sector, private sector and civil society. Unfortunately, we do not have resources for working with civil society, so we are working mainly with public and private sectors. We try to identify the risks and work together with other agents and stakeholders in Sweden" (TI).

Anti-corruption risk assessment is part of the United Nations Global Compact as a platform for the development, implementation and disclosure of responsible corporate policies and practices and corporate sustainability initiative in the world with over 12,000 signatories based in 145 countries (A Guide for AntiCorruption Risk-Assessment, 2013). Risk-assessment tools are included in the majority of contemporary compliance systems and become a crucial starting point for creating and implementing policies (Zadek, 2007). Identification of different kinds of risk (financial, reputational, etc.) allows not only making a relevant policy, but also assessing the effectiveness of its implementation, and building a "risk mitigation plan" (Touil, 2016). International methods of risk assessment allow to assess risks for certain companies, industries and countries.

"As a telecom industry company, we have big corruption risks because we create networks and have to make deals with public authorities... When we are entering a country, we should assess different kinds of risks: what is the level of corruption in the country, how business is organised, and so on" ('Telia').

Risk assessment as a methodological tool is also used in the business code for flagging the most dangerous zones so that to pay attention to improper gifts and benefits for specific groups. The code stresses on the 
"red flags" for each audience, for example, for a group with specific restriction of the frequency of benefits and lack of connection to the recipient's work are identified as the risk zones (Code on Gifts, 2014).

The second challenge for Swedish anti-corruption work is the difficulties in identification of misconduct, especially in the ethical sphere, in cases of gifts, favours, conflicts of interests, nepotism etc., where sometimes every case should be considered individually. Every organisation elaborates codes and rules for anti-corruption regulation but in real life, they always face situations that do not fall into the legislation. The Swedish Anti-Corruption Institute created the ethical committee for such individual cases, with involvement of different experts, most of which are experienced lawyers. Such situations are also discussed in umbrella organisations with participation of police; during seminars and conferences, etc. Every anti-corruption agent understands that despite the existing law, many cases must be considered individually; and the rules must always be discussed or sometimes amended. The principle of self-regulation means the necessity to adapt the rules to a particular organisation, sphere and business, to make it internal and specific.

"If we look at the definition of CSR (corporate social responsibility), it is a broad field, and is changing all the time, it is dynamic... We always think in terms what we would expect from companies how to be legitimated stakeholders in society. It becomes incredibly important to me that compliance codes, codes of conducts are live documents. They need to be amended depending on what society expects from companies" (ICC).

The third big challenge for anti-corruption activities in every sector of Swedish society is the necessity to develop the culture of integrity in society and in a particular organisation. Swedish mentality is not tolerant to corruption; however, nobody is free from the temptation to make extra money and get benefit from people's positions. Anti-corruption civil society provides many tools for everyday anti-corruption work, raising people's awareness, attracting their attention to corruption issues.

A long-time period of stability, long-time traditions of free media, transparent culture, social trust and trust to the government in society - all these factors can be considered as indicators of culture with a high level of integrity and low level of corruption. At the same time, new challenges for international companies, ethical issues in the public and private spheres generate a need for continuous work to improve anti-corruption policy and development of culture of integrity.

"...we have seen that the knowledge about risks is not as solid as it should be, both in the public sector and in the private sector. We have rapidly growing export markets. So, there are no reasons to be concerned, but we do not stop working with these issues" (IMM).

Low whistleblowing and reporting activity is another problem that has been stressed by different respondents. Making new laws about whistleblowing and the existing tools and supportive institutions for protecting whistleblowers do not mean that the majority of people in Sweden are ready to report about corruption. One of the main factors here is the limited internal labour market and difficulties with the protection of anonymity inside and even outside a company. People are afraid that internal whistleblowing can put them in a vulnerable position that can cause personal conflicts, countermeasures from the employer and other trouble in their workplace (Hedin, Månsson, 2012). The same problem is with whistleblowing on the local level where people are reluctant to speak up against their neighbours and current or potential partners.

\section{Conclusions}

The Swedish ACS is not a part of the mass "popular movement" that attracts millions of people for solving important problems. Two traditional anti-corruption organisations in Sweden - Transparency International and Anti-Corruption Institute - do not work directly with ordinary people; they mostly collaborate with governmental institutions in changing legislation and policies (lobbying for changes) or assist business 
in elaborating and implementing codes of conduct. At the same time, anti-corruption activity of civil society in Sweden can be considered as part of wider social movements for human rights, democracy and integrity; especially at international level. This activity is also included in different compliance programs in the business sector. Regular journalistic investigations and free access to the official data ensure awareness for ordinary people about corruption cases. At the same time, anti-corruption activity is a sphere of partnership between the state, business and the non-profit sector. Anti-corruption agenda is one of the good examples of common practices and collaboration between different spheres of Swedish society. The police organise outreach work with: authorities, business, and umbrella organisations to raise awareness; NGOs and special private organisations to support business in their compliance work. Besides, media investigations become the basis for the official corruption prosecution. Such networks create opportunities for exchange of resources between different types of agents and for effective cooperation and consensus in this area.

Orientation to changing society and making progress is the key agenda for different stakeholders in Sweden. The main way for achieving this goal is the necessity to work with intentional markets where unsustainability can thwart business goals. The international (EU, UN, OECD, ISO, etc.) policies and laws demand to pay attention to corporate responsibility (Petschow et al., 2005). NGOs as the transmitters of international rules contribute to the state governance and business regulations by getting involved in different public and private activities, making strategic partnerships and coalitions. At the same time, the state and government need to be oriented to social challenges and keep pace with civic movements.

Anti-corruption agenda is not widely spread in the Swedish public discourse as a part of political mottos or election companies. Large corruption scandals at the government and business levels, as well as active international involvement in different spheres (the EU and GRECO requirements, development of compliance systems around the world as part of sustainable business) have launched the processes of revision of anticorruption legislation and ethical regulation. According to the EU Anti-Corruption Report, some of the areas that require further attention are transparency of financing of political parties, transparency in public procurement, monitoring of compliance at the local government level (The EU Anti-Corruption Report, 2014: 270). However, the laws should reflect real values and attitudes in Swedish society: this is the main principle of creating policies in Sweden. For this reason, the discussions with different agents about education and training to develop integrity and ethics in different public and private spheres remain a very important part of the Swedish ACS's activity. The research has shown that the civil society's ability to create networks with the state, business and other agents is the main condition for the so-called horizontal accountability, sustainability, and preventing corruption in Swedish society that, in its turn, has been established over a long period of building the culture of integrity and civic institutions.

\section{Acknowledgments}

The research was supported by Visby Scholarship from Swedish Institute, reference number 00327/2017.

\section{References}

A Guide for Anti-Corruption Risk-Assessment. (2013). United Nations Global Compact Office. Available at: https:// www.unglobalcompact.org/docs/issues_doc/Anti-Corruption/RiskAssessmentGuide.pdf [Accessed: March 17, 2018].

A policy for civil society. Fact sheet. (2010). Government Offices of Sweden. Available at: https://www.regeringen. se/contentassets/e7c7d467b3e141f8b87ec4589c201fd5/a-policy-for-civil-society [Accessed: November 30, 2017].

Andersson, S. (2002). Corruption in Sweden Exploring Danger Zones and Change. Umeå: Department of Political Science, Umeå University.

Bergh, A., Sjolin, M. (2016). A Clean House: Studies of Corruption in Sweden. Lund: Nordic Academic Press.

Carr, I. Outhwaite, O. (2011). The Role of Non-Governmental Organizations (NGOs) in Combating Corruption: Theory and Practice. Suffolk University Review, Vol. XLIV, No. 3, p. 615-664.

Code on Gifts, Rewards and other Benefits in Business. (2014). The Swedish Anti-Corruption Institute. Available at: http://www.institutetmotmutor.se/en/publications/business-code/ [Accessed: February 12, 2018]. 
Corruption Perceptions Index 2017. (2018). Transparency International. Available at: https://www.transparency.org/ news/feature/corruption_perceptions_index_2017 [Accessed: February 8, 2018].

Elliott, K. A. (1997). Corruption as an International Policy Problem: Overview and Recommendations. Corruption and the Global Economy. Washington, DC: Institute for International Economics, p. 175-233.

Graeff, P., Svendsen, G. T. (2013). Trust and Corruption: The Influence of Positive and Negative Social Capital on the Economic Development in the European Union. Qual Quant, Vol. 47, p. 2829-2846.

Guiding Principles on Business and Human Rights. (2011). UN. Available at: https://www.ohchr.org/Documents/Publications/GuidingPrinciplesBusinessHR_EN.pdf [Accessed: May 4, 2018].

Hedin, U., Månsson, S. A. (2012). Whistleblowing Processes in Swedish Public Organisations - Complaints and Consequences. European Journal of Social Work, Vol. 15, No. 2, p. 151-167.

Heinrich, F., Brown, A. J. (2017). Measuring Accountability and its relevance for anti-corruption: introducing a new integrity system-based measure. Clime Law and Social Change, Vol. 68, p. 359-381.

Holloway, R. (2006). NGO Corruption Fighters' Resource Book - How NGOs can use monitoring and advocacy to fight corruption. Available at: http://www.sasanet.org/curriculum_final/downlaods/CA/Books\%20\&\%20Articles/B3\%20 -\%20NGO\%20Corruption\%20Fighters_resource\%20book.pdf [Accessed: November 13, 2017].

ILO Core Conventions. (2018). Available at: http://www.ilo.org/global/standards/introduction-to-international-labourstandards/conventions-and-recommendations/lang--en/index.htm [Accessed: February 4, 2018 ].

Introducing a Risk-Based Approach to Regulate Businesses. (2014). World Bank Group. Available at: http://www.wds. worldbank.org/external/default/WDSContentServer/WDSP/IB/2014/09/18/000333037_20140918121617/Rendered/PDF/907540BRI0Box30d0approach0Sept02013.pdf [Accessed: February 13, 2018].

Lundberg, E. (2017). Toward a New Social Contract? The Participation of Civil Society in Swedish Welfare Policymaking, 1958-2012. Voluntas: International Journal of Voluntary and Nonprofit Organizations, p. 1-22. Available at: https://doi.org/10.1007/s11266-017-9919-0 [Accessed: January 8, 2018].

Moroff, H., Schmidt-Pfister, D. (2010). Anti-Corruption Movements, Mechanisms, and Machines - an Introduction. Global Crime, Vol. 11, No. 2, p. 89-98.

Mungiu-Pippidi, A. (2013). Controlling Corruption through Collective Actions. Journal of Democracy, Vol. 24, No. 1, p. 101-115.

OECD guidelines for multinational enterprises. (2015). Available at: http://www.oecd.org/investment/mne/ [Accessed: September 16, 2017].

Olsson, S. A. (2014). Corruption and Political Participation: A Multilevel Analysis. QoG Working Paper Series. Gothenburg: University of Gothenburg.

Pestoff, V. A. (2008). A Democratic Architecture for the Welfare State (Routledge Studies in the Management of Voluntary and Non-Profit Organizations). London, New-York: Routledge.

Petschow, U., Rosenau, J., von Weizsäcker, E. U. (2005). Governance and Sustainability: New Challenges for States, Companies and Civil Society. Sheffield: Greenleaf publishing.

Reported Corruption in Sweden: Structure, risk factors and countermeasures. (2013). The Swedish National Council for Crime Prevention (Brå). Available at: https://www.bra.se/download/18.12caa4f91440b31239f1f ed/1395400931424/2013_22_Reported_Corruption_in_Sweden.pdf [Accessed: February 3, 2018].

Rothstein, B. (2001). Social Capital in the Social Democratic Welfare State. Politics and Society, Vol. 29, No. 2, p. 207241.

Rothstein, B., Eek, D. (2009). Political Corruption and Social Trust. Rationality and Society, Vol. 21, No. 1, p. 81-112.

Rothstein, B., Uslaner, E. M. (2005). All for All: Equality, Corruption, and Social Trust. World Politics, Vol. 58, No. 1, p. 41-72.

Special Eurobarometer - 470: Corruption Report. (2017). European Union. Available at: http://ec.europa.eu/commfrontoffice/publicopinion [Accessed: February 8, 2018].

Svallfors, S. (2011). A Bedrock of Support? Trends in Welfare State Attitudes in Sweden, 1981-2010s. Social Policy \& Administration, Vol. 45, No. 7, p. 806-825.

Swedish Anti-Corruption Legislation. (2016). A Summary Legal Guide. Available at: http://www.nymanrudenstam.se/ wp/wp-content/uploads/2016/05/Booklet_Swedish-anti-corruption-legislation-1601-002.pdf [Accessed: February $15,2018]$.

The Anti-Bribery and Anti-Corruption Review. (2014). Ed. by M. F. Mendelsohn. Derbyshire: Encompass Print Solutions.

The World Bank's Strategy on Governance and Anti-Corruption - a Civil Society Perspective. (2017). A CIDSE Background Paper. Available at: https://www.trocaire.org/sites/default/files/resources/policy/world-bank-governance.pdf [Accessed: December 11, 2017].

Themudo, N. S. (2013). Reassessing the Impact of Civil Society: Nonprofit Sector, Press Freedom, and Corruption. Synthesis of Lessons Learned of Donor Practices in Fighting Corruption. Governance, Vol. 26, No. 3, p. 63-89. 
Touil, K. (2016). Risk Based Approach: Understanding and Implementation. ACAMS. Available at: http://files.acams. org/pdfs/2016/Risk-Based_Approach_Understanding_and_Implementation_K_Touil.pdf [Accessed: February 11, 2018].

Transforming our world: the 2030 Agenda for Sustainable Development. (2015). UN General Assembly. Available at: https://sustainabledevelopment.un.org/post2015/transformingourworld [Accessed: January 15, 2018].

UN Global Compact. (2018). Available at: https://www.unglobalcompact.org/ [Accessed: November 14, 2017 ].

UN Office of Drugs and Crime, the global programme against corruption: UN anticorruption toolkit. (2004). Available at: http://www.unodc.org/documents/corruption/publications_toolkit_sep04.pdf [Accessed: February 4, 2018].

Văduva, S., Alistar, V. T., ThomasIoan, A. R., Fotea, I. S., Lupiţu, D., Neagoie, A. S., Cioară, D. F. (2016). Integrity in the Business Panorama. Models of European Best-Practices. Berlin: SpringerBriefs in Business.

Wijkström, F. (2004). The Role of Civil Society: The Case of Sweden in International Comparison. Paper prepared for and presented at the 1st International Korean Studies Workshop on "Civil Society \& Consolidating Democracy in Comparative Perspective", May 21-22, Yonsei University. Available at: https://www.researchgate.net/publication/5093173_The_Role_of_Civil_Society_The_Case_of_Sweden_in_International_Comparison [Accessed: February 4,2018$]$.

Zadek, S. (2007). The Civil Corporation. London: Earthscan Publications.

\title{
Cited interviews
}

Secretary-general of the Swedish Anti-Corruption Institute - Institutet Mot Mutor (IMM).

Executive secretary of Transparency International - Sweden (TI).

Chief Superintendent of the Swedish National Anti-Corruption Police Unit (NACPU).

Compliance manager of Telia Company (Telia).

Partner and Senior Advisor of WhistleB, Whistleblowing Centre (WhistleB).

\section{ANTIKORUPCINE PILIETINE ŠVEDIJOS VISUOMENË - TVARIOS POLITIKOS TINKLO DALIS}

\author{
Marina MaKarova \\ Udmurtijos valstybinis universitetas (Rusija)
}

\section{Santrauka}

Šiame straipsnyje siekiama atskleisti, kaip pagrindiniai Švedijos gerovès valstybės principai - suinteresuotujų subjektų daugumos; patikimumo ir bendradarbiavimo - veikia pilietinės visuomenès kovą su korupcija. Atliekant tyrimą taikomi šie empiriniai metodai: dokumentų analizė ir interviu su ekspertais. Atskleista, kad pilietinès visuomenès antikorupcinè veikla Švedijoje gali būti traktuojama kaip socialinių judejjimų, susijusių su žmogaus teisèmis, demokratija ir vientisumu, dalis, ypač tarptautiniu lygmeniu. Švedijoje yra nemažai įvairių asociacijų ir sajungų, kurios, be kitų bendrų veiksmų, skatina kovoti su korupcija, valstybès organizacijose ir komercinèse įmonėse nustatant atitinkamas taisykles. Valstybė ir vyriausybè turètu orientuotis ị socialinius iššūkius ir neatsilikti nuo pilietinių judèjimų. Partnerystè su skirtingomis suinteresuotosiomis šalimis yra pagrindinė Švedijos antikorupcinės pilietinès visuomenès veikla, padedanti siekti tikslų, vengiant korumpuotos elgsenos. Kovos su korupcija politikos tinklai yra dvejopo bendradarbiavimo rezultatas: antikorupcinio dalyvavimo ir antikorupcinių paslaugų.

Tyrimai atskleidè, kad pilietinès visuomenès gebejjimas kurti tinklus su valstybès, verslo ir kitais subjektais yra pagrindinè vadinamosios horizontaliosios atskaitomybės ir tvarumo bei korupcijos prevencijos Švedijos visuomenėje sąlyga. Tai užtikrina nepaliaujamas sąžiningumo kultūros pilietinėse institucijose puoselejjimas. 
Kovos su korupcija tematika, kaip politinių motyvų ar rinkiminių kampanijų dalis Švedijos viešajame diskurse, nèra labai populiari. Korupcijos skandalai vyriausybėje ir verslo struktūrose, aktyvus dalyvavimas ịvairiuose tarptautiniuose projektuose pradejo pakeisti antikorupcijos ịstatymus ir nustatyti etiško reguliavimo procesus.

Remiantis ES kovos su korupcija ataskaita, kai kurioms sritims būtina skirti daugiau dèmesio: politinių partijų finansavimo ir viešujų pirkimų skaidrumas, atitikties stebėsena vietos valdžios lygiu. Vis dẻlto ịstatymai turètų remtis amžinosiomis vertybėmis ir atskleisti Švedijos visuomenės požiūrị, toks pagrindinis valstybės politikos kūrimo principas. Todèl diskusijos su ịvairiais subjektais apie švietimą ir mokymą, siekiant ugdyti vientisumą ir etiką ịvairiose viešose ir privačiose srityse, išlieka svarbi Švedijos pilietinès visuomenès antikorupcinès veiklos dalis.

PAGRINDINIAI ŽODŽIAI: korupcija, pilietiné visuomene, politikos tinklai.

JEL KLASIFIKACIJA: H7, I0, I3.

Received: 2018.07.10

Revised: 2018.08.23

Accepted: 2018.08.28 